Témoigner Témoigner. Entre histoire et mémoire

Getuigen Revue pluridisciplinaire de la Fondation Auschwitz

\title{
Kun/moet je (in) Auschwitz spelen?
}

De weergave van de Holocaust in kamp van Hotel Modern

Peut-on/doit-on jouer (à) Auschwitz? La représentation de la Shoah dans le spectacle Kamp de la compagnie Hotel Modern

\section{Charlotte Bouteille-Meister}

Traducteur : Gorik de Henau

\section{(2) OpenEdition}

\section{Journals}

Édition électronique

URL : https://journals.openedition.org/temoigner/3273

DOI : $10.4000 /$ temoigner.3273

ISSN : 2506-6390

Cet article est une traduction de :

Peut-on/doit-on jouer (à) Auschwitz ? - URL : https://journals.openedition.org/temoigner/3261 [fr]

Éditeur :

Éditions du Centre d'études et de documentation Mémoire d'Auschwitz, Éditions Kimé

Édition imprimée

Date de publication : 1 octobre 2015

Pagination : 47-58

ISSN : 2031-4183

Référence électronique

Charlotte Bouteille-Meister, «Kun/moet je (in) Auschwitz spelen? », Témoigner. Entre histoire et mémoire [Online], 121 | 2015, Online op 01 octobre 2016, geraadpleegd op 04 février 2022. URL: http:// journals.openedition.org/temoigner/3273 ; DOl: https://doi.org/10.4000/temoigner.3273 


\section{Kan/moet je (in) Auschwitz spelen? \\ De weergave van de Holocaust in Kamp van Hotel Modern}

$\rightarrow$ Charlotte BouteilleMeister, Université Paris Ouest Nanterre La Défense

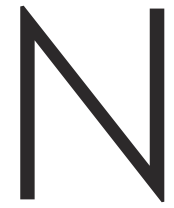

aar de Holocaust wordt vaak verwezen als een zo uitzonderlijke gebeurtenis dat ze niet objectief kan beschouwd en dus ook niet weergegeven kan worden. Via een extreem gewelddadig proces werd de menselijkheid van anderen op industriële schaal ontkend, op een manier die alle ethische categorieën en de grenzen tussen het menselijke en het onmenselijke overschreed. Elke poging tot verbeelding en uitbeelding lijkt uitgesloten, zowel mentaal - het zich voor de geest halen - als figuurlijk - het weergeven in woorden, beelden, of in bewegende beelden (film) en 'bewegende aanwezigheid' (theater).

In de woorden van de overlevenden zelf blijft de gebeurtenis de stempel dragen van het onvoorstelbare, het ondenkbare en het onhoorbare. De individuele ervaring van de kampen is zo buitensporig dat de menselijke geest het moeilijk zou hebben om haar te vatten, om te vormen tot denkobject en dus over te brengen. In Frankrijk werd het onvoorstelbare karakter van de Holocaust tot op zekere hoogte versterkt door het debat over het ontoonbare. Door het verbod van Claude Lanzmann (Lanzmann 1994) werd een tijd lang elke fictieve en/of verbeelde uitbeelding van de volkerenmoord op de Europese Joden gediskwalificeerd; alleen de waarheid en waardigheid van de getuigenis werd aanvaard, in die mate dat zelfs in twijfel werd getrokken of archiefbeelden van de nazivernietigingskampen legitiem waren of überhaupt bestonden (Didi-Huberman 2003).

Het uitbeelden van de Holocaust met figuren wordt dus vaak a priori als onmogelijk, onbetamelijk en dom bestempeld. Dit heeft er waarschijnlijk toe bijgedragen dat Kamp van het Nederlandse gezelschap Hotel Modern maar driemaal in Frankrijk werd opgevoerd: in 2006 in La Ferme du Buisson (Festival Temps d'images), in 2008 in Théâtre 71 in Malakoff (Festival MAR.T.O) en in 2013 in Centquatre (opnieuw in het raam van het Festival Temps d'images, dus geprogrammeerd door diezelfde José-Manuel Gonçalvès). Hun voorstelling De Grote Oorlog daarentegen, over hoe soldaten in de loopgraven dag in dag uit de eerste wereldbrand beleefden, wordt sinds haar première in 2000 geregeld gespeeld in de Franse toneelhuizen (Bouteille-Meister 2008), onlangs nog ter gelegenheid van de herdenking van honderd jaar Eerste Wereldoorlog. Toch raakten de leden van Hotel Modern er net van overtuigd om het thema van de Holocaust aan te kaarten via hun zo bijzondere scenische 
Kan/moet je (in) Auschwitz spelen? (vervolg) manier van werken toen ze tijdens het creëren van De Grote Oorlog een expressieve verwantschap ontdekten tussen hun spectaculaire medium en het uitbeelden van extreem geweld. Pauline Kalker, Herman Helle en Arlène Hoornweg brengen gefilmd poppentheater, waarbij ze in het volle zicht menselijke figuurtjes hanteren in kleine schaalmodellen en op een achterscherm beelden projecteren die live op de planken worden gedraaid. Zo geven ze gestalte aan het landschap van de Auschwitz-kampen.

Door gebruik te maken van een pop, dat wil zeggen een personage af te beelden via een voorwerp, kunnen ze voor de ogen van de toeschouwers het onvoorstelbare juist objectiveren en het ontoonbare ombuigen in een weergave van de Holocaust. Het werkstuk van Hotel Modern ontsnapt aan een dubbel ethisch risico: enerzijds het Lanzmann-verbod waarmee de verbeelding wordt geloochend waarop alle kennis berust, wat ons uiteindelijk kan veroordelen tot onwetendheid en zelfs onverschilligheid; anderzijds een louterende identificatie van de toeschouwers, onbetamelijk in het licht van het buitensporige lijden van de gedeporteerden. De zowel stomme als ontzettend expressieve beelden van Kamp belichamen tegelijk de eis tot stilte en de verplichting om te schreeuwen, en houden op die manier een diep ethische weergave van de Holocaust in. Het ethische belang van het uitbeelden heeft ook een cognitieve dimensie. Auschwitz opvoeren in een kamp op verkleinde schaal komt onvermijdelijk neer op Auschwitz spelen, zoals je oorlogje speelt met tinnen soldaatjes. Dit 'spel' met een huiveringwekkende misdaad tegen de mensheid zou aanstootgevend overkomen als het gezelschap niet resoluut stelde dat 'het tegendeel van het spel niet de ernst is, maar... de werkelijkheid', om de woorden van Freud aan te halen (Freud 1988, 34). Door de Holocaust uit te beelden via een spel op de planken, via de ver-beeld-ing (want beeld en fictie zijn hier met elkaar verbonden), treed je niet in concurrentie met de werkelijkheid in een poging haar te assimileren of te vervangen, maar produceer je kennis over de menselijke soort. Hotel Modern wijst de argumenten van de hand volgens dewelke het geweld van de beulen, net als dat van de bevolking die het aanmoedigde of er zich niet tegen verzette, onbegrijpelijk is. Het gezelschap onderzoekt in tegendeel de volmaakte 'denkbaarheid' van dat geweld door het op te voeren, op serieuze, symbolische en ver-beeld-e wijze. Hotel Modern stelt dat ze Kamp maakten 'om de waarheid van de Holocaust te realiseren, op een heel praktische manier, om hem te kunnen verbeelden, om dichter te komen bij de kern van wat is gebeurd' (Perrier 2006, 94) - waarmee ze zich aansluiten bij wat Georges Didi-Huberman schrijft in de beginregels van Images malgré tout: 'Om te weten moet je je verbeelding gebruiken.' (Didi-Huberman 2003, 11, vertaling GdH)

HET 'POPPENTHEATER' IN KAMP:

\section{EEN VORMELIJKE STRATEGIE TEGEN HET ONTOONBARE}

In Kamp krijgt het publiek een schaalmodel te zien van de kampen Auschwitz (Auschwitz I) en Auschwitz-Birkenau (Auschwitz II), gereproduceerd met acht centimeter hoge figuurtjes. Los van het ruimtelijk dichterbij plaatsen van de twee kampen, het invoegen van het vrouwenkamp in het mannenkamp in Birkenau en 


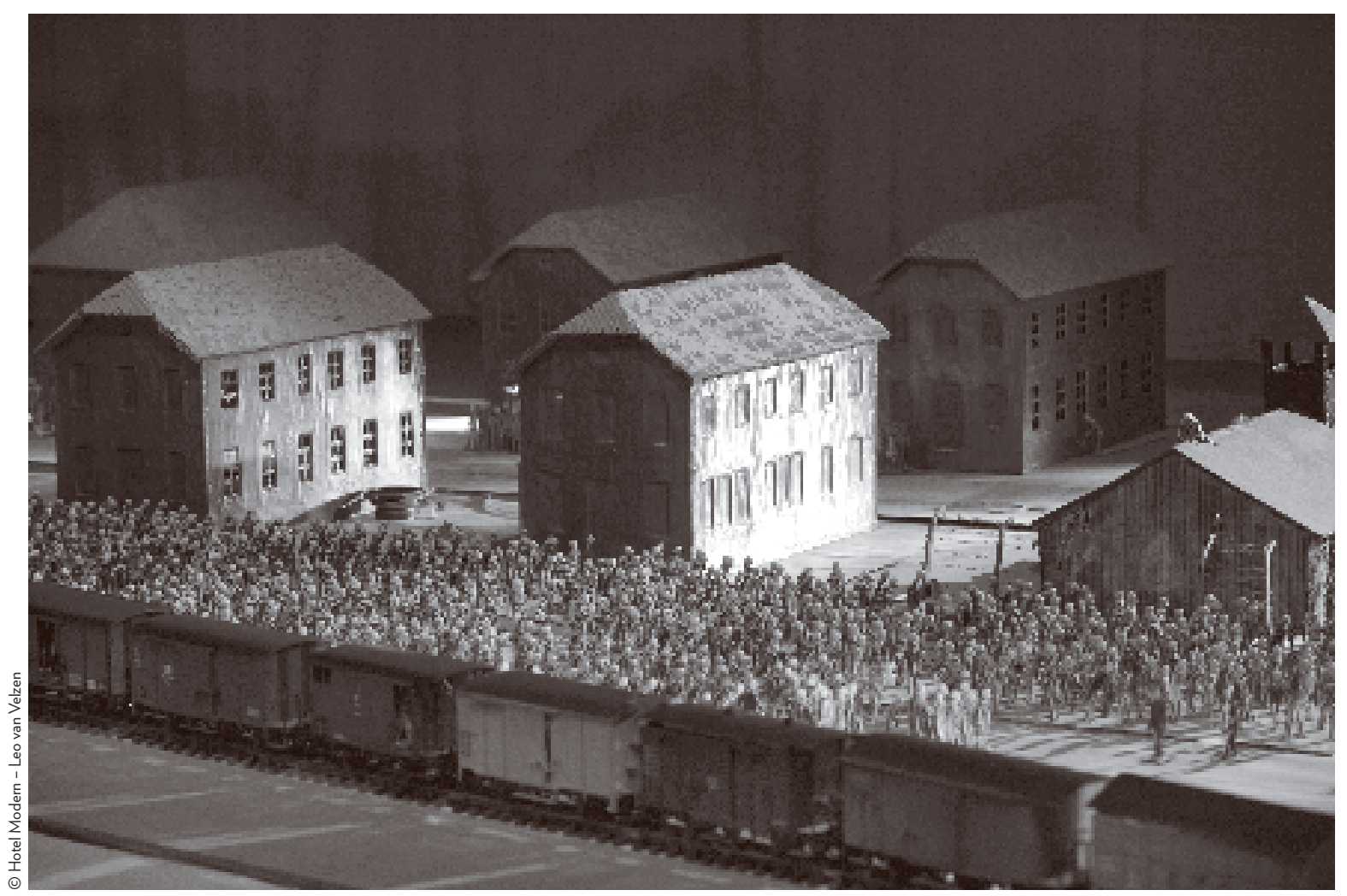

het kleinere aantal houten barakken blijft het schaalmodel van ca. $100 \mathrm{~m}^{2}$ trouw aan de topografie van de jaren 1940-1944; een aantal houten barakken is er zelfs onder constructie, want het Lager van Birkenau werd nooit volledig afgewerkt. Op een ondergrond van beige karton tekenen zich contouren af die voor de eenentwintigste-eeuwse toeschouwer schrikwekkend vertrouwd zijn: de pantsertoren midden op het gebouw dat boven de ingang van Birkenau uitsteekt, het cynische motto Arbeit macht frei op het fronton van de toegangspoort in Auschwitz, de prefabstallen die tot Blocks zijn omgevormd in Birkenau, het 'platform van de dood' waar de gedeporteerden wachten die uit de beestenwagens zijn gestapt, de dubbele rij met geëlektrificeerde prikkeldraad op gebogen masten, dit alles onder de dreigende controle van de uitkijkposten. In het verlengde van het langdurige en nauwgezette documentaire opzoekingswerk van het gezelschap wordt er uitzonderlijk veel aandacht besteed aan details, wat tot uiting komt in de close-ups die in de achtergrond worden geprojecteerd op het lichtgrijze doek waarmee de drie gesloten zijden van het toneel zijn ingepakt. De voorstelling wordt namelijk voortdurend gefilmd met kleine lageresolutiecamera's, waarvan de beelden live worden getoond. De toeschouwer ziet dus 'in het levensgroot' hoe de drie vertolkers de figuurtjes in de maquette hanteren, en tegelijk ziet hij de 'film', van nabij gedraaid en met een strakke, gezochte compositie, waardoor zijn blik sterk op een welbepaalde actie wordt gericht. 


\section{DOSSIER}

Kan/moet je (in)

Auschwitz spelen?

(vervolg)
Het kamp waaraan de voorstelling op veelbetekenende wijze haar naam ontleent, is er het belangrijkste personage van. In een eerste episode in de onafgewerkte barakken wordt de opbouw van het kamp geschetst op de klanken van het Horst-WesselLied (het lied van de SA, later het lied van de NSDAP), waardoor de opgevoerde feiten worden gesitueerd in de geschiedenis en in het Endlösung-project van het Derde Rijk. Daarna krijg je, gedurende 45 minuten, het verloop van een dag in Auschwitz te zien. Van de winterse ochtend tot de pikdonkere nacht wordt in negen scènes de gruwel getoond van de concentratiekampen en het vernietigingssysteem van de nazi's. Wat de toeschouwer te zien krijgt, is niet zozeer het lot van de gedeporteerden, als wel de dagelijkse werking van een doodsfabriek, een stad die erop is gericht om haar bewoners te doden, op snelle of trage, maar altijd efficiënte wijze.

De 'fabel', die met haar extreme eenvoud en brutaliteit onverdraaglijk, ja zelfs schandelijk belachelijk zou zijn als ze door acteurs werd vertolkt, wordt maar mogelijk door het medium waar de theatermakers voor kozen, namelijk poppentheater dat door zijn aard voortdurend laveert tussen het grootst mogelijke realistische en het grootst mogelijke irreële effect. Poppen zijn dubbel: ze behoren wél en ook niet tot het menselijke domein, het zijn voorwerpen en mensen, ze zijn stom en je kunt ze een stem geven. In dat opzicht beelden de figuurtjes die het kamp 'bevolken' de gedeporteerden uit op juiste en tegelijk krachtige wijze want door een fenomeen van 'overdracht' (Perrier 2006, 95), eigen aan poppen, worden emotie en afstand met elkaar verbonden. Het wordt mogelijk om zeer gewelddadige scènes met maximaal effect te tonen. Poppen zijn immers geen acteurs, en dus is de kwestie van het trukeren niet aan de orde. Het geweld dat de poppen ondergaan wordt door de grote intensiteit voor het publiek paradoxaal genoeg reëler, dit in tegenstelling tot de dood van door een acteur vertolkt personage, waarbij de toeschouwer altijd het 'fictieve' karakter voor ogen houdt. Vermits poppen tijdelijk bezielde voor-

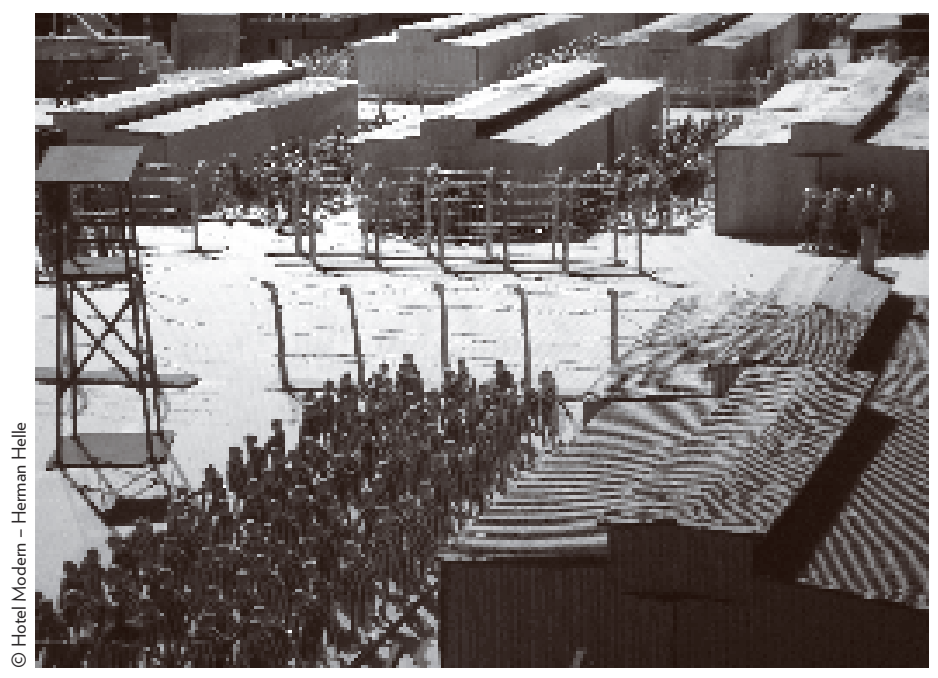
werpen zijn, 'gelooft' de toeschouwer in de terechtstelling ervan op de planken en ervaart de bijbehorende schok (emotie), maar hij wendt het hoofd niet af uit walging of afgrijzen (afstand). Dit tweevoudige 'overdrachteffect' wordt nog versterkt door het feit dat de figuurtjes en schaalmodellen thuishoren in de wereld van de kinderjaren en door de toeschouwers spontaan bekoorlijk worden gevonden, wat onmiddellijk in tegenspraak is met het enorme geweld dat in Kamp aan de orde is.

De meer dan 3000 figuurtjes werden met de hand gemaakt door een team van een vijftiental kunstenaars. Een structuur in ijzerdraad wordt licht aangedikt met een 'lichaam' van doorzichtig hars, bekleed met 


\section{EXTREEM GEWELD OP/IN SCÈNE}

een gevangenisuniform in gestreepte stof en zonder ster zodat geen onderscheid kan gemaakt worden tussen Joodse gedetineerden, 'politieke' gevangenen en homoseksuelen. Het enige Joodse teken in de hele voorstelling is een zevenarmige kandelaar tussen de voorwerpen die de gedeporteerden worden afgenomen en bijeengebracht in de 'Canada' van het kamp. Boven op het lichaam van de figuurtjes komt een hoofd in porseleinaarde dat met de hand wordt vormgegeven en telkens uniek is. De gezichten roepen het personage uit De schreeuw van Edvard Munch op. Het zijn angstwekkende figuren, je ziet alleen hun twee holle ogen en een tot een gat gereduceerde mond; ondanks de stilte eigen aan voorwerpen schreeuwen ze het uit en roepen het publiek op om het schouwspel van hun stomme maar onmiskenbare lijden te aanzien. Dankzij het dubbele karakter van de poppen krijgen de slachtoffers van Auschwitz, die het in het concentratiekampsysteem zonder menselijkheid, naam, gezicht of zelfs een graf moesten stellen, een nieuw en dus menselijkgezicht. Maar in dezelfde beweging slaagt het gezelschap erin om het vernietigingsproces op te voeren waarvan ze het slachtoffer waren. Een voorbeeld: in de scène waarin de gedeporteerden zich ontkleden voor ze de gaskamer binnengaan wordt via een jurk die over het harslichaam van een gedetineerde glijdt de extreme broosheid duidelijk van een leven dat op het punt staat te verdwijnen. De enscenering roept schroom op, en laat tegelijkertijd een blijvende indruk na bij de toeschouwer. Tegen het vernietigingsstreven van de nazi's in gaat het erom de poging tot ontmenselijking uit te drukken en toch menselijkheid op te eisen, via de vreemde aan/afwezigheid van die poppen met hun zo expressieve witte gezichten en hun doorzichtige, stemloze lichamen. In zijn artikel in Le Monde over Schindler's List herinnert Claude Lanzmann aan het begin van zijn film Shoah: twee overlevenden van het Vilna-getto vertellen hoe ze in 1944 werden verplicht om de massagraven te openen en met blote handen te werken op lijken 'die er steeds meer als platte schijven gingen uitzien. Hoe dieper ze groeven, hoe platter de lichamen werden en de Duitsers verboden hun het woord "dode" of "slachtoffer" te gebruiken. Ze moesten ze Figuren noemen, dat wil zeggen poppen, marionetten.' (Lanzmann 1994) De keuze om de Holocaustslachtoffers in Kamp uit te beelden door middel van Figuren net voor hun dood komt neer op het beschrijven van de vernietiging en het verzet daartegen.

Hoewel Pauline Kalker en Arlène Hoornweg bij bepaalde sequenties uit De grote oorlog passages uit soldatenbrieven voorlazen, beslisten de leden van Hotel Modern na verschillende vruchteloze pogingen om in Kamp geen teksten te gebruiken. Ze slaagden er niet in om de woorden, zelfs die van kampoverlevenden, in de wereld van de poppen te integreren, waarschijnlijk vanwege hun schreeuwende gezichten (de figuurtjes in De grote oorlog hebben geen gezicht) en het feit dat de woorden wellicht niet hadden kunnen opboksen tegen de handelingen op de planken, waardoor een, weliswaar stilzwijgende, opvoering noodzakelijk werd.

De noodzaak om de toeschouwers bij de les te houden uit respect voor de schandelijke feiten bracht het gezelschap er ook toe om niet direct op de planken te laten zien hoe de 'filmsoundtrack' bij de voorstelling tot stand komt, dit in tegenstelling tot hun andere voorstellingen, waar een geluidsman zichtbaar op het toneel aanwezig 
Kan/moet je (in) Auschwitz spelen? (vervolg) is. Toch wordt de klank, net als de op het achterdoek geprojecteerde beelden, door Ruud van der Pluijm live vanuit de regiekamer gemaakt, vertrekkend van geluiden die worden opgenomen met contactmicrofoons onder het toneel en klanken die Hotel Modern zelf in Auschwitz ging opnemen: de wind die waait op de Poolse vlakte, het geknars van een wagen, een vogel die zingt in de vooravond. Woorden mogen dan ontbreken, maar de geluidsband loopt ononderbroken door en draagt sterk bij tot het 'realistische effect' dat de film van de voorstelling paradoxaal genoeg veroorzaakt. De realistische klankenpracht blijft nog vrij dicht bij de ervaring van de gedetineerden - waarschijnlijk waait de wind in die landschappen tegenwoordig met dezelfde koude hevigheid als tijdens de jaren veertig - maar is tegelijk uitermate onstoffelijk en zonder 'reële' materialiteit, want dat had in dit miniatuurconcentratiekamp van papier en doek obsceen kunnen zijn. Op die manier bevestigen de makers van Kamp de ethische stellingname van hun voorstelling; ze willen namelijk een realistisch effect creëren waardoor de toeschouwers worden geschokt, maar tegelijk erkennen ze het onbereikbare karakter van de kamprealiteit, zonder ooit te verzaken aan het verlangen om die op te voeren.

Kamp nodigt het publiek uit om het schouwspel van de grote moordmachine van Auschwitz te aanschouwen. De makers balanceren tussen een uiterst precies gereconstrueerde maquette en de ostentatieve keuze om die met karton te bouwen, tussen de expressieve gezichten van de afzonderlijke figuurtjes en de kostuums uit fotokopiepapier van de SS-officieren en de gevangenen die nog in stadskledij gekleed gaan. De poppen zijn tegelijk mensen en voorwerpen. Hotel Modern claimt de noodzaak om 'ondanks alles' toch uit te beelden en laat duidelijk een 'cesuur' zien tussen een niet te verbeelden ervaring en haar verbeelde weergave.

\section{JEZELF FILMEN TERWIJL JE AUSCHWITZ FILMT: EEN UITBEELDING VAN DE 'CESUUR'}

Ik ontleen hier het concept 'cesuur' aan Walter Benjamin, die in zijn Réflexions théoriques sur la connaissance (Theoretische reflecties over de kennis) de taak van de materialistische historicus definieert als het redden van een 'dialectisch beeld' (Benjamin 1993, 494, vertaling GdH) van het verleden via het heden. Dit dialectische beeld moet worden losgerukt uit het onproblematische continuüm van de Universele Geschiedenis en worden 'stopgezet' om de 'barst' (Id., 491) aan het licht te brengen:

Het is niet correct dat het verleden het heden verklaart of vice versa. Veeleer ontmoet het Vroeger als in een flits het Nu via een beeld en vormt zo een constellatie. Met andere woorden, een beeld is stopgezette dialectiek. [...] Het beeld dat wordt gelezen - daarmee bedoel ik het beeld in het Nu van zijn kenbaarheid - draagt bij uitstek het kenteken van het kritieke, hachelijke moment waarop elke lectuur berust. (Id., 479-480)

Via de 'cesuur' kunnen we de scheuring onthullen die de ramp in de geschiedenis veroorzaakt en, in dezelfde beweging, het verleden 'in het Nu van zijn kenbaarheid' 
weer actueel maken, door de historische continuïteit af te wijzen 'die het verleden reduceert tot wat het was en is geweest. Een herhaling van zichzelf' (Ombrosi 2006, 279). In 'Over het concept van de geschiedenis' doet Benjamin 'het continuüm van de geschiedenis uiteenspatten' om daar de fenomenen in de vorm van 'constellatie[s]' uit te halen, zodat het heden zich erdoor 'betracht' weet. Dat doet hij op de symbolische wijze van de 'cesuur', want het beeld van het verleden is een vluchtig beeld, dat het heden als passage moet vatten:

Het echte beeld is in een flits voorbij. Je kunt het verleden maar vasthouden in een beeld dat steevast opkomt en verdwijnt op het moment zelf dat het zich laat kennen. [...] Het is een voorgoed verloren beeld van het verleden dat dreigt te verdwijnen met elk heden dat er zich niet door betracht weet. (Benjamin 2000, 430)

Het heden moet zich de erfgenaam tonen van de messiaanse verwachting van het verleden, en als de actualiteit het verleden wil raken moet die erfenis een levende (en geen 'archaïsche' of 'patrimoniale'; Benjamin 2000, 480, 491) weergave zijn, maar tegelijk het absolute vervagen van dit 'beeld' van het verleden bevestigen.

De scenische opstelling in Kamp lijkt te beantwoorden aan die dubbele eis van het verleden aan het heden: levende weergave en cesuur zijn. Ze doet dat via de beeltenis, die zowel vreemd menselijk en levendig is als radicaal anders en levenloos, maar ook door het gebruik van video tijdens de voorstelling.

De beelden die live op de planken worden gefilmd en geprojecteerd op het achterdoek veroorzaken een verrassend 'realistisch effect', want ze appelleren aan wat het publiek zich van het gebeurde 'herinnert'. Met uitzondering van de Holocaustoverlevenden die de voorstelling bijwonen, komen de beelden van Hotel Modern voor ons niet als waarachtig of levendig over omdat ze zouden overeenstemmen met persoonlijke herinneringen, maar wel omdat ze beantwoorden aan een indirecte collectieve herinnering van de feiten, grotendeels berustend op de foto- en filmbeelden die de geallieerden draaiden toen ze de kampen bevrijdden. Die fotografische beelden, die we kennen uit geschiedenisboeken en documentaires, hebben een bepaald beeld van de kampen voor altijd in ons geheugen gegrift - een beeld dat, wanneer het wordt gereactiveerd, voor de toeschouwer als een waarmerk van echtheid geldt.

De Hollywoodcineast George Stevens, hoofd van de Special Coverage Unit die de opdracht had om voor het proces van Neurenberg filmisch bewijs van de concentratie- en vernietigingskampen aan te dragen, filmde Dachau met Kodachromekleurenfilm. Maar uit vrees dat het tribunaal niet zou zijn uitgerust met een aangepaste projector, koos het Amerikaanse leger voor monochrome film, een 'beslissing die zou bijdragen tot het hardnekkige culturele beeld van de Holocaust als een gebeurtenis die zich in zwart-wit had afgespeeld' (Douglas 2001, 31). Steven Spielberg draaide Schinder's List niet toevallig in zwart-wit. Hotel Modern gebruikt kleine lageresolutiecamera's, waardoor het beeld er grijzig gaat uitzien, en voert bovendien een bijna kleurloos kamp op. Op die manier sluit het gezelschap aan 
Kan/moet je (in) Auschwitz spelen? (vervolg) bij de collectieve representatie van de Holocaust en roept het bij de toeschouwer beelden op die in zijn geheugen rondspoken, als evenzovele tekenen die paradoxaal genoeg als 'waarachtiger' gelden dan kleurenbeelden. De wereld van de massamoord is voor ons een zwart-witwereld.

Hotel Modern roept beelden uit het verleden op (via het scherm) in het heden van de voorstelling (door de maquette) en slaagt er zo in een 'beeld' te creëren in de benjaminiaanse zin van het woord, dat wil zeggen een weergave van het verleden waarin 'het Vroeger het Nu ontmoet [...] om een constellatie te vormen'. In de ontmoeting/confrontatie van de twee vlakken van de spectaculaire Kamp-opstelling worden momenten uit het verleden als het ware uitgekristalliseerd of weer actueel gemaakt, via een effect dat berust op een historische syncope en een radicale esthetiek. De kijker voelt zich door dat verleden 'betracht' en kan in het geluid van de wind die over de vlakte jaagt het gefluister van de gedeporteerden vermoeden:

Het verleden draagt de sporen van een geheim teken dat verwijst naar de verlossing. Voelen we zelf niet een zuchtje van de lucht waarin de mensen uit het verleden leefden? Vormen de stemmen waar we naar luisteren niet een echo van weggestorven stemmen? (Benjamin 2000, 428)

De stemmen blijven evenwel 'weggestorven', net als die van de stomme poppen in Kamp, want die 'verlossing' van het verleden door het heden is in een flits voorbij. Op net dezelfde manier verschijnen de filmbeelden van Hotel Modern kortstondig op het achterdoek en verdwijnen zonder te worden geregistreerd. Ook zij kunnen maar een 'constellatie' vormen in het moment van hun 'ontmoeting' met het heden van de maquette en de toeschouwers die ernaar kijken. In Kamp wordt geenszins een 'verlossing' nagestreefd van de in Auschwitz gepleegde misdaden. Dat brokstukken van het verleden kortstondig worden gered betekent hoegenaamd niet dat vertolkers en publiek absolutie of troost vinden. Door de rol van beul te spelen, verplichten de leden van Hotel Modern ons integendeel om de uitermate ongemakkelijke positie in te nemen van getuigen in het heden en dus figuurlijke medeplichtigen.

\section{VERTOLKERS-BEULEN EN TOESCHOUWERS-MEDEPLICHTIGEN: EEN 'VERLOSSING' ZONDER TROOST}

Met de bijzondere scenische opstelling van Kamp kan Hotel Modern het standpunt van de folteraars innemen en de buitengewoon menselijke dimensie laten zien van de in Auschwitz gepleegde wreedheden. Door de gevangenenpoppen in het kamp te verplaatsen en hen ter dood te brengen nemen de vertolkers van het gezelschap, in de 'ruime' context van de maquette, de positie van de beulen in en domineren ze met hun gestalte de minuscule figuurtjes. In de ophangingsscène komt bijvoorbeeld een reusachtige mensenhand het krukje onder de voeten van de veroordeelden wegtrekken. Door de Auschwitz-kampen in het klein te reconstrueren, naar eigen zeggen een 'krankzinnig' project dat de makers vaak aan hun onderneming deed 


\section{EXTREEM GEWELD OP/IN SCÈNE}

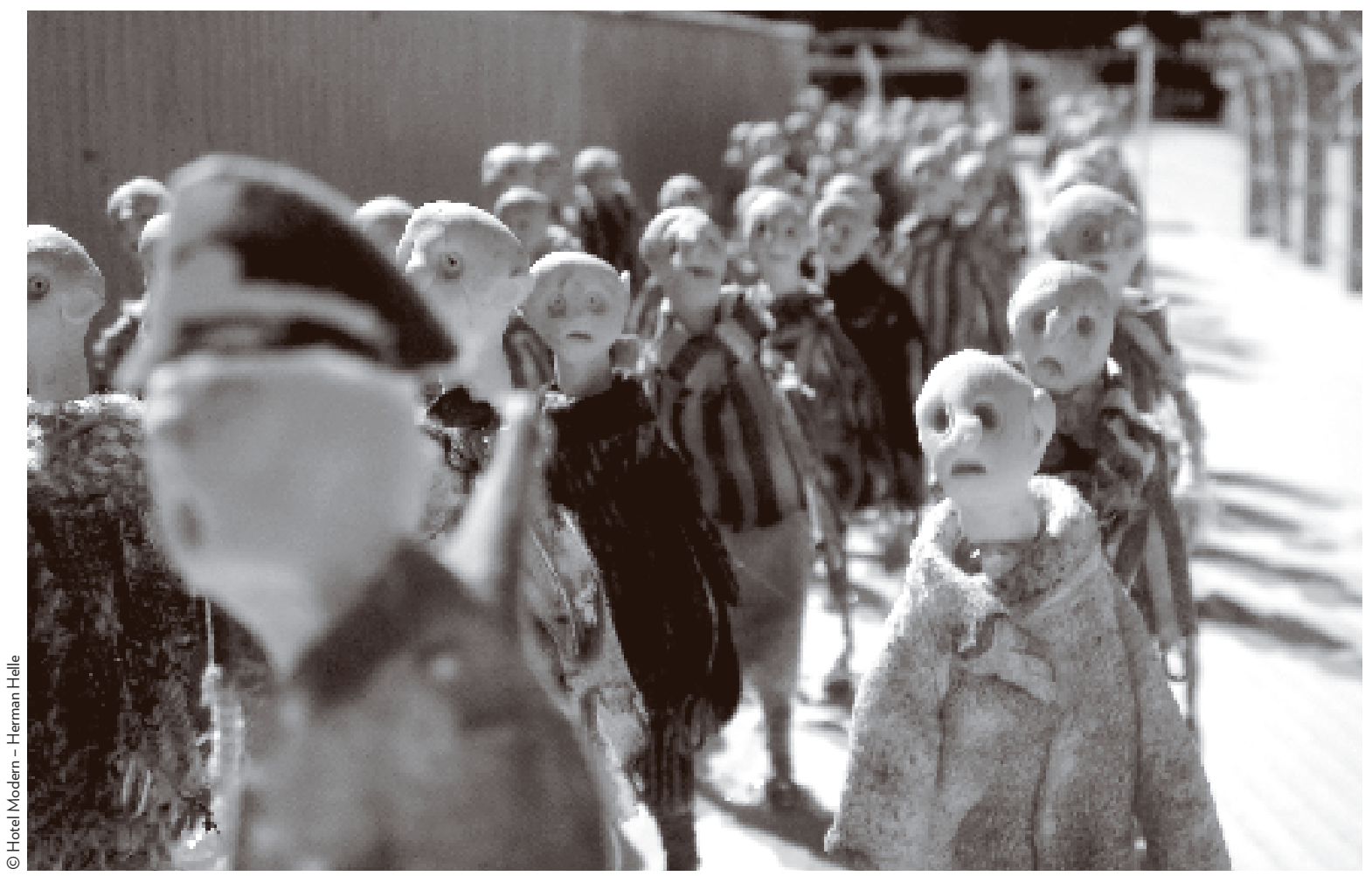

twijfelen, ervaarden ze het psychologische mechanisme waarop de werking van het kamp berustte:

Naargelang we de voorstelling in elkaar staken, gingen we de beulen begrijpen. In het begin waren de figuurtjes echte personages, dan maakten we er meer en meer en het werden nummers, we moesten dozen maken om ze op te bergen: dozen voor de mannen, dozen voor de vrouwen, dozen voor de SS'ers enzovoort. We moesten onder de figuurtjes zelfs een selectie doorvoeren, met een cameratest; wie het beste overkwam, kreeg een betere 'rol'. We moesten die duizenden mensen 'beheren' en dat was niet anders dan de SS-officieren die in de kampen leven en dood van duizenden gevangenen moesten organiseren. [...] Onze figuurtjes droegen een nummer, we begonnen werkelijk 'greep te krijgen' op de organisatie en logistiek. [...] Toen Herman [Helle] de miniatuurgaskamer maakte, echt krankzinnig, onderzocht hij de afstand tussen de gaskamers en het crematorium in Auschwitz-Birkenau. Hij verbaasde zichzelf toen hij opmerkte dat het 'helemaal niet praktisch was', en zei: 'Ik wil verbeteringen aanbrengen in Auschwitz!' Dat is ook wat er in psychologisch opzicht met de daders van de slachtingen is gebeurd. [...] De mensen die in de kampen werkten, moesten voortdurend praktische oplossingen bedenken en dat zie je ook in de voorstelling; die brengt geen portret van de personages, maar van die grote machine. Het was geen routineklus, maar creatief werk; het ligt in de menselijke natuur om problemen te willen oplossen, bijvoorbeeld een oven maken zonder rook. Het is niet 
Kan/moet je (in) Auschwitz spelen? (vervolg) zo gek of moeilijk om in de schoenen van de beulen te gaan staan; dat het is gebeurd valt heel eenvoudig te begrijpen, maar je moet het wel willen begrijpen. [...] Als je stelt: 'Ons probleem zijn de Joden', dan is het niet moeilijk om geleidelijk te werk te gaan tot je alleen as overhoudt; het was een proces dat heel wat vernuft veronderstelde, en waaraan heel wat personen meewerkten. [...] In de voorstelling hebben we getracht om via de camera dat proces en die organisatie te laten zien. (Kalker 2010)

Van G. Didi-Hubermans stelling 'Om te weten moet je je verbeelding gebruiken' stelt Hotel Modern de volgende variant voor: 'Om te begrijpen moet je doen alsof' (Perrier 2006, 94). Door te doen alsof ze SS-officieren zijn in figuurlijke zin - 'overgezet' in een toneelopvoering met poppen, waardoor het onwerkelijke karakter ervan duidelijk wordt - en door zich te buigen over de 'logistiek' die nodig is om 'leven' en 'dood' te organiseren van ettelijke duizenden figuurtjes van papier en doek, plaatsen de makers van Kamp de Endlösung in een menselijke context en stellen ze opnieuw de vraag hoe zoveel mensen aan een dergelijke wreedheid hebben kunnen meewerken. Er is geen onmenselijkheid in Auschwitz in de zin van een vlucht van het menselijke, al net zo min als er in Kamp een verschil bestaat tussen het gezicht van de gedeporteerden en dat van de SS-ers. Het verschil betreft alleen de positie en de (tot in het extreme doorgevoerde) scheiding van taken, wat uitmondt in een volledig verlies van de morele betekenis van handelingen. Wat Hotel Modern ons met zijn voorstelling tracht duidelijk te maken, via ver-beeld-ing en toneelspel, is de fundamenteel en buitengewoon menselijke dimensie van de handelingen die we te zien krijgen. Door die niet los te koppelen van onze menselijkheid en door te weigeren om ze te verwijzen naar de categorie van het 'ondenkbare' en het 'niet-mededeelbare', verkrijgen ze die benjaminiaanse 'verlossing'. Dat houdt in geen geval vergeving of absolutie in; veeleer gaat het om de nagedachtenis die we zijn verschuldigd aan alle slachtoffers van de - menselijke - barbaarsheid van de nazikampen.

Die nagedachtenis, zoals ze in Kamp te zien is, is niet opbeurend, maar net bijzonder ongemakkelijk voor de toeschouwer, die tegenover de scheppers-beulen in de positie wordt gedwongen van getuige-medeplichtige van de opgevoerde feiten.

Omdat de nazi's tijdens het oprukken van de geallieerde troepen bewijzen vernietigden, beschikken we over bitter weinig foto's van de kampen gedurende hun werking. Ons visuele geheugen van de Holocaust is dan ook voor het grootste deel afkomstig van foto's van de angstwekkende 'resultaten' van de nazibarbaarsheid en niet van de totstandkoming daarvan. Een van de technieken dievaak worden gebruikt om de echtheid van die 'achteraffoto's' te bewijzen is onweerlegbare ooggetuigen in de context te plaatsen, bijvoorbeeld Duitse burgers die gedwongen worden naar de massagraven te kijken (Douglas 2001, 36). De aanwezigheid van die getuigen op de foto's 'ontslaat' wie ernaar kijkt in zekere zin van de morele verplichting om tegen de afgebeelde feiten in actie te treden. Ze geven aan dat de gewelddaden voorbij zijn, dat we ons in het daarna bevinden. In Kamp daarentegen vinden de wreedheden in het heden plaats: 'Het speelt zich voor je ogen af. Als je de voorstelling ziet, gebeurt het opnieuw.' (Perrier 2006, 95) De misdaden worden gepleegd in het gedeelde heden van 
vertolkers, poppen en toeschouwers, die door hun positie zelf machteloos staan tegenover het geweld; vanwege hun 'ongepaste' gestalte worden ze door de kampwereld in schaalmodel uitgesloten en net zo worden ze door het geprojecteerde, tweedimensionale beeld op hun waarnemersplaats vastgepind. Als onmachtige getuigen van het geweld op het toneel - op het moment zelf dat het wordt gepleegd en niet in het achteraf van filmbeelden bij de bevrijding van de kampen - worden we in een positie van

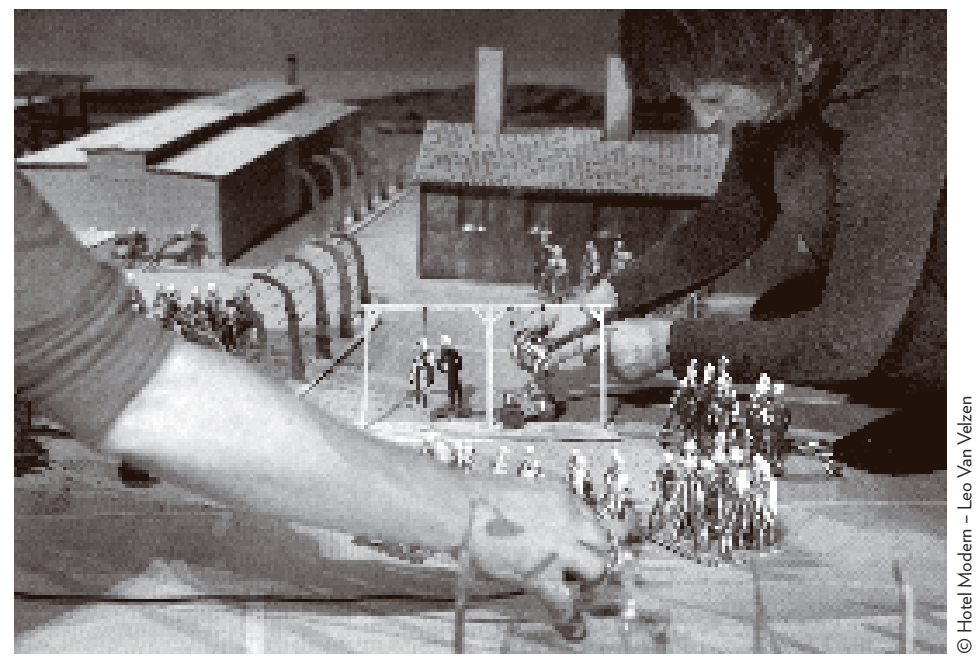
'medeplichtigen' gedwongen. We doen niets om er een einde aan te maken en we kunnen ook niet op symbolische wijze toevlucht zoeken bij de gevangenen want die staan apart door hun poppenstatuut en door de beelden die nooit vanuit het standpunt van de gedeporteerden worden gedraaid - met uitzondering van de tweede sequentie in de gaskamer. De camera's nemen namelijk meestal een perspectief vanuit de hoogte aan, dat met geen enkel 'personage' in het kamp wordt verbonden; het is de blik van een getuige, maar in tegenstelling tot de archiefbeelden komt die getuige zelf niet in het plaatje voor. De lege plek in het beeld moet worden ingenomen door de toeschouwer, die de rol krijgt toebedeeld van getuige in het heden, zwijgzaam, machteloos en in fine medeplichtig. Wie het proces van de Endlösung wil begrijpen via de opvoering ervan, moet ook het nietsdoen begrijpen van de bevolking in en rond de kampen. De toeschouwer is verplicht om er via een kijkspel de ‘overgedragen' ervaring van mee te maken.

In Kamp is het publiek aanwezig bij een schouwspel van extreem menselijk geweld; door de vreemde aan/afwezigheid van de poppen kan het niet wegkijken en zich al evenmin met de slachtoffers identificeren. Zelfs de scène die vanuit de gesloten gaskamer wordt gefilmd - waarin je de Zyklon B-kristallen via een gat in de zoldering ziet binnenkomen, en het beeld troebel en daarna zwart wordt - toont duidelijk aan dat je via een figuurlijke weergave kunt trachten om 'de diepte waarin de gedeporteerden zich bevonden' (Perrier 2006, 95) zo dicht mogelijk te benaderen, zonder die ooit te bereiken. De blik van de toeschouwer in Kamp blijft die van de externe getuige-medeplichtige, opgeroepen om zowel de afstand als het verband te ervaren tussen het kampgeweld zonder getuigen en de fotografische of filmische 'gevolgen' daarvan, die met hun getuigenissen in ons geheugen blijven rondspoken. In de laatste sequentie van de voorstelling is een long shot te zien van de massagraven in Auschwitz, waarin de verhakkelde lijken heel wat realistischer worden afgebeeld dan de figuurtjes van de levende gedeporteerden - als om te onderstrepen dat de 'realistische' beelden uit het verleden, waardoor we de Holocaust kennen, het resultaat zijn van een actuele verschrikking waarvan we via de 'overdracht' van de voorstelling getuigen zijn geworden. 
Kan/moet je (in) Auschwitz spelen? (vervolg)
Tegen de gedachtegang van het ontoonbare in beweert Hotel Modern dat je moreel verplicht bent 'af te beelden' om te begrijpen. Daar de ervaring van de slachtoffers niet objectiveerbaar en voor altijd onbereikbaar is - want de toeschouwer kan de gedeporteerden-poppen niet vergezellen tot aan de dood - kunnen we alleen via de positie van beulen en medeplichtigen van dichtbij toegang krijgen tot de psychologische mechanismen met betrekking tot de Holocaust. Dat 'menselijke' erfgoed van extreem geweld moeten we ons eigen maken om leven en dood van de kampgevangenen vrij te kopen, om dat beeld voor even los te rukken uit het historische continuüm waardoor alle gebeurtenissen worden gelijkgeschakeld en in de vergetelheid raken. Als inderdaad - zoals Jean-Luc Godard in Histoire(s) du cinéma beweert over de beelden die George Stevens in Dachau draaide - 'een eenvoudige rechthoek / van 35 / millimeter / de eer redt / van al wat werkelijk is' (Godard 1998, 88), dan kunnen de Kamp-poppen in hun onwerkelijke werkelijkheid zwijgend de 'voor eeuwig weggestorven' stemmen doen weerklinken van de Joodse mannen, vrouwen en kinderen die naar de gaskamers werden gebracht.

Vertaling: Gorik de Henau 